\title{
SEX AND AGE DIFFERENCES IN LEVELS OF ANOMIA OF LATVIAN INHABITANTS
}

\author{
Jel̦ena L̦evina \\ Kristīne Mārtinsone \\ Rīga Stradinš̌ University, Latvia \\ Daiga Kamerāde \\ University of Birmingham, United Kingdom
}

\begin{abstract}
Anomia is one of the important factors, which can influence the psychological wellbeing of individuals. It is especially valuable to determine those socio-demographic groups which can demonstrate the highest levels of anomia. The purpose of the research was to determine whether there are sex and age differences in levels of anomia of Latvian inhabitants. The secondary data from the third European Quality of Life Survey (EQLS) were used. The sample consisted of Latvian inhabitants $(n=1009)$, aged from 18 to 92 years (male-34.9\%, female-65.1\%). 3 indices and 3 subscales of anomia (Social Distrust, Social Isolation and Meaninglessness) were constructed (L̦evina, Mārtinsone \& Kamerāde, 2015a, 2015b). A multivariate analysis of variance was conducted. It was found that there was a significant difference in multidimensional anomia between Latvian inhabitants of different age groups.
\end{abstract}

Keywords: anomia, meaninglessness, social distrust, social isolation.

\section{Introduction}

Anomia is one of the important factors, which can influence the psychological well-being of individuals. Anomie refers to the condition or state, in which there is a breakdown of social norms and guidance for the citizens of a society (Durkheim, 1893), as well as to the discrepancy between common social goals and the legitimate means to attain those goals (Merton, 1964). Anomia is subjectively perceived anomie (Olsen, 1969; Srole, 1956; Lytkina, 2012).

Anomie is recognised as one of the most important concepts in sociology and criminology (Cao et al., 2010). However, there is the lack of anomia research in the field of psychology. Thus, this study is focused on anomia.

Research of anomia is actual in the period when the society endure social and economic changes. It is especially valuable to determine those sociodemographic groups which can be more sensitive and vulnerable to socioeconomic changes and transitions and can demonstrate the highest levels of anomia.

The purpose of this research was to determine whether there are sex and age differences in levels of anomia of Latvian inhabitants. 
Method of the research - analysis of the secondary data from the third European Quality of Life Survey (European Quality of Life Survey (EQLS), 2012).

Participants - the inhabitants of Latvia $(n=1009)$, aged from 18 to 92 years (male $-34.9 \%$, female $-65.1 \%$ ).

Instrument - the Anomia Scale developed on the base of the questionnaire of the EQLS and the integrative multidimensional model of anomia (Levina, Mārtinsone \& Kamerāde, 2015a, 2015b).

\section{The concept of anomia}

Despite of the great importance of anomia, there are certain gaps and problems in the field of both theoretical and empirical research, such as the lack of clear definition of anomia, the existence of problems with operationalization and measurement of anomia.

\section{The notion of anomia}

The concept of anomia was introduced by Leo Srole (Srole, 1956), who distinguished between two levels of existence of the phenomenon - macrosocial level (anomie) and microindividual level (anomia). Anomia refers to microindividal level and can be understood as the individual impact of anomie. According to Srole anomia is an individual's generalized sense of "self-others alienation".

E. Lytkina (Лыткина, 2014) offers to differ three notions: anomie as a social phenomenon, anomia as an individually psychological state of a person, and anomy as a psychological state of anxiety, distrust, pessimism, hopelessness the loss of a sense of safety. She also emphasizes that the notion of anomy is more relevant to psychological studies and psychological measures. At the same time in her empirical studies (Lytkina, 2012) she differentiates between the two concepts - anomie, which stands for a state of society characterized by the lack of norms and regulations, and anomia, which characterizes the level of individual state of members of the society.

Thus, anomie is an objective social state of the society. In turn, anomia is a subjectively perceived anomie, an individually psychological state, characterized by subjectively perceived normlessness and such feelings as helplessness, alienation, and concern about future.

\section{The structure of anomia}

The analysis of literature allows to conclude that different researchers of anomie and anomia conceptualized these phenomena as consisting of different dimensions.

First of all Durkheim's (Durkheim, 1966) definition of anomie was connected to the idea of social isolation and normlessness. In turn, Robert Merton (Merton, 1962) treated the concept of anomie as normlessness.

Srole (Srole, 1956) conceptualized three dimensions of anomia: norm devaluation, referring to deflation of moral guidelines in goal-striving, 
interpersonal disintegration, referring to the destabilization of interpersonal supports, and future foreclosure expressing the abandonment of further goalstriving.

Some researchers analyze the concept of anomy through the prism of the theory of alienation. Alienation is conceptualized as having five major components or dimensions: powerlessness, normlessness, social isolation, meaninglessness, and self-estrangement (Dean, 1961; Seeman, 1959). According to Seeman (Seeman, 1959) anomia refers to normlessness and is therefore one of the indicators of alienation. Later Seeman (Seeman, 1982) describes two aspects of anomia - normlessness and meaninglessness.

Lytkina (Лыткина, 2014) recognizes the same dimensions of anomia normlessness and meaninglessness. Respectively she has constructed the two indices of anomia.

Examination of the existing literature allows one to conclude that anomia is multidimensional. However, at the same time researchers conceptualized the dimensions of anomia differentially. Some dimensions are similar, some specific.

\section{The integrative multidimensional model of anomia}

On the base of the analysis of theoretical and empirical research of anomia the integrative multidimensional model of anomia was developed (L,evina, Mārtinsone \& Kamerāde, 2015a, 2015b; Levina, Martinsone et al., 2014). The model includes three main dimensions of anomia, such as normlessness, meaninglessness, and social isolation.

The first dimension of anomia - normlessness - could be defined as a perceived breakdown of the social order in which norms no longer regulate behavior. This dimension can be divided into two sub-dimensions - an individual's deviation from prescribed rules or customs and social distrust. Two main signs of an individual's deviation from prescribed rules or customs are the lack of an individual's respect of presumed norms and readiness to engage in particular acts of deviance and to use non-normative means. In its turn, the lack of trustworthiness to government and other social institutions as well as trustworthiness to other people, that is the extent to which people doubt that others are generally fair, honest and respect presumed norms, are main signs of social distrust.

The second dimension of anomia is meaninglessness. Meaninglessness as an absence or unclarity of prescriptions for behavior is divided into the lack of goal clarity and generalized sense of meaninglessness. The lack of goal clarity is being without desirable and sensible goals. On the other hand, the main signs of the generalized sense of meaninglessness are the sense of the lack of control and freedom, the sense of boredom. 
At last the third dimension of anomia - social isolation was divided into two sub-dimensions - estrangement to others and cultural isolation. The lack of social support, the sense of loneliness are the signs of the estrangement to others, when the sense of loss of internalized social norms and values is the main signs of the cultural isolation.

As a result of the review of theories and empirical research of anomia one possible representation of the integrative multidimensional model of anomia was developed (see Fig. 1).

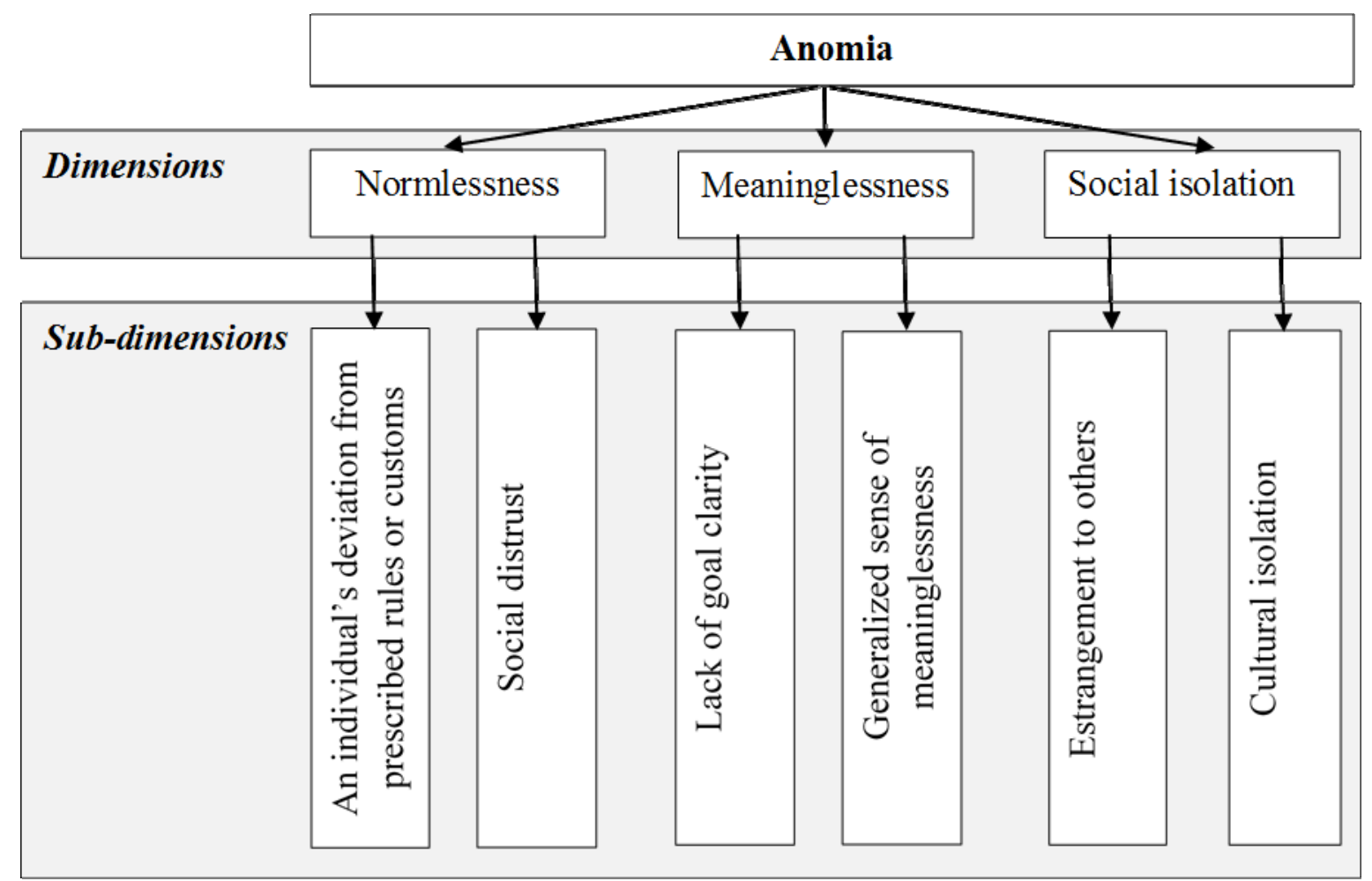

Figure 1. Representation of the integrative multidimensional model of anomia (Ḷevina, Mārtinsone, \& Kamerāde, 2015b)

Thus, the concept of anomia can be defined as an individual's characteristic when the person beliefs that there are no social norms, rules and prescriptions, which can regulate his / her own behavior as well as the behavior of other citizens of the society, when the person endures the psychological state of meaninglessness and social isolation.

\section{Anomia and its association with sex and age}

Examination of the existing literature allows to conclude that in previous studies researchers have investigated how individuals' sense of anomie, t.i. anomia is related to the social and economic position of the individual in a society. Some studies of determinants of anomie have also focused on the relationship between such variables as sex and age and subjectively perceived anomie. 
Cao and co-authors (Cao et al., 2010; Zhao \& Cao, 2010) measured individuals' sense of anomie as an index of the individual's acceptance of the legitimacy of different instrumental criminal scenarios such as violations of laws for monetary gains. It is important to note that Cao and co-authors use the term "anomie" and at the same time, they emphasize that the research object is anomie at the individual level, t.i. individuals' sense of anomie, in other words anomia. They reported that it was found that male respondents had a higher level of anomie than female respondents. Similarly, young people reported an elevated level of anomie than seniors. The authors concluded that at the individual level, the older one is the less anomic one becomes; men are more likely to report a stronger sense of anomie than women. Thus, in their study Cao and co-authors found that such aspect of anomia as normlessness and more precisely - an individual's deviation from prescribed rules - is related to gender and age.

Sev'er and co-authors (Sev'er et al., 1993) measured subjectively perceived anomie by a modified version of Leo Srole's Anomie Scale (Srole, 1956). Sev'er and co-authors found that that the main effect of gender on subjective perceptions of anomie was not significant. However, there was a significant interaction between ethnic groups and gender. The authors concluded that there were no anomie gender differences in most of the high ethnic status groups, but some lower status gender variations were found.

Some previous investigations have focused on such dimension of anomia as meaninglessness and sex differences. Some researchers report that sex and anomia are not associated (Richmond et al., 1969). However, in other studies there was found that men did express more meaninglessness than females (Metha, 1972).

\section{The present study}

Examination of the existing literature allows to conclude that in some previous studies researchers have focused on relations between sex and age and a single certain dimension of anomia. Thus, the main objective of this study was to investigate whether males and females of different age differ in multiple dimensions of anomia. Second, the results of the previous studies of the links between anomia and sex are inconsistent - some researchers have found that there were sex differences in levels of subjectively perceived anomie while other investigators concluded that anomia and sex were not associated. Third, there is a lack of research about interaction between sex and age group. Thus, in the current study there are three main research questions:

1. Are there any sex differences in levels of multidimensional anomia for Latvian inhabitants? If yes, what are they?

2. Are there any age differences in levels of multidimensional anomia for Latvian inhabitants? If yes, what are they? 
3. Is there a significant interaction between the effects of sex and age of Latvian inhabitants on levels of multidimensional anomia?

\section{Methodology}

In this study the secondary data from the third European Quality of Life Survey (European Quality of Life Survey (EQLS), 2012) were used. The EQLS is carried out every four years and examines the objective circumstances of European citizens' lives and how they feel about those circumstances and their lives in general.

The third EQLS took place in 2011-2012 in 34 countries. The Latvian sample consisted of the inhabitants of Latvia $(n=1009)$, aged from 18 to 92 years (male $-34.9 \%$, female $-65.1 \%$ ).

All Latvian respondents were classified into four age groups according to periodization of human development (Craig \& Baucum, 2001): late adolescents / youths (from 18 to 21 years old), early adults (from 22 to 40 years old), middle adults (from 41 to 65 years old), and late adults (66 and older).

On the base of the questionnaire of the EQLS and the integrative multidimensional model of anomia (Ľevina, Mārtinsone \& Kamerāde, 2015a, $2015 \mathrm{~b}$ ) three indices of anomia and respectively three subscales, which measure different dimensions of anomia, were constructed.

At the first stage of the construction of the Anomia Scale all original questions of the EQLS were analyzed and compared with different dimensions, subdimensions, and signs of anomia. Thus, based on the integrative multidimensional model of anomia the initial item pool was chosen. The first item pool consisted of 21 items. Some of the original items of the EQLS initially were negatively worded. These items were reversed. Each score for all items was converted to a $\mathrm{z}$-score.

Based on the results of the psychometric analysis, the number of items was reduced to 13. Thus, the newly established Anomia Scale consists of 13 items that form three subscales: Social Distrust $(k=6)$, Social Isolation $(k=3)$, and Meaninglessness $(k=4)$. Cronbach's alpha coefficients for all subscales were computed (the coefficients ranged from .69 to .84).

A brief description of the three subscales of anomia is as follows:

1. Social distrust - the higher score means the lower level of trustworthiness to government and other social institutions;

2. Social Isolation - the higher score means the higher ratings of lack of social support, being without social recognition, sense of loneliness;

3. Meaninglessness - the higher score means the higher ratings of being without desirable and worthwhile goals, sense of lack of control and freedom, pessimism about the future. 


\section{Results}

As it was mentioned above, the main purpose of this research was to determine whether there are sex and age differences in levels of anomia of Latvian inhabitants. Descriptive statistics for measures of anomia for male and female respondents from different age groups are presented in Table 1.

Table 1. Means and Standard Deviations for Anomia Scales as a Function of Age and Sex

\begin{tabular}{cccccccc}
\hline & & \multicolumn{5}{c}{ Anomia Scales } \\
\cline { 3 - 8 } Group & $\boldsymbol{n}$ & \multicolumn{2}{c}{ Social Distrust } & \multicolumn{2}{c}{ Social Isolation } & \multicolumn{2}{c}{ Meaninglessness } \\
\cline { 3 - 8 } & & $\boldsymbol{M}$ & $\boldsymbol{S D}$ & $\boldsymbol{M}$ & $\boldsymbol{S D}$ & $\boldsymbol{M}$ & $\boldsymbol{S D}$ \\
\hline $\begin{array}{c}18-21 \text { years } \\
\text { Males }\end{array}$ & 20 & -.56 & 3.65 & -.87 & 1.92 & -1.43 & 2.16 \\
Females & 26 & -.41 & 4.00 & -.39 & 1.74 & -1.78 & 1.79 \\
22-40 years & & & & & & & \\
Males & 114 & .44 & 3.95 & -.68 & 2.14 & -.87 & 2.75 \\
Females & 125 & .00 & 4.13 & -.38 & 2.09 & -.47 & 2.50 \\
$41-65$ years & & & & & & & \\
Males & 114 & 1.53 & 4.22 & .43 & 2.70 & .41 & 2.74 \\
Females & 213 & -.16 & 4.43 & -.09 & 2.58 & -.04 & 2.80 \\
$66-92$ years & & & & & & & \\
Males & 45 & -.02 & 4.61 & .45 & 2.36 & -.23 & 2.85 \\
Females & 145 & -.78 & 4.63 & -.12 & 2.27 & .16 & 3.13 \\
\hline
\end{tabular}

The levels of Social Distrust, Social Isolation and Meaninglessness for male and female respondents from different age groups are also presented in Figure 2.
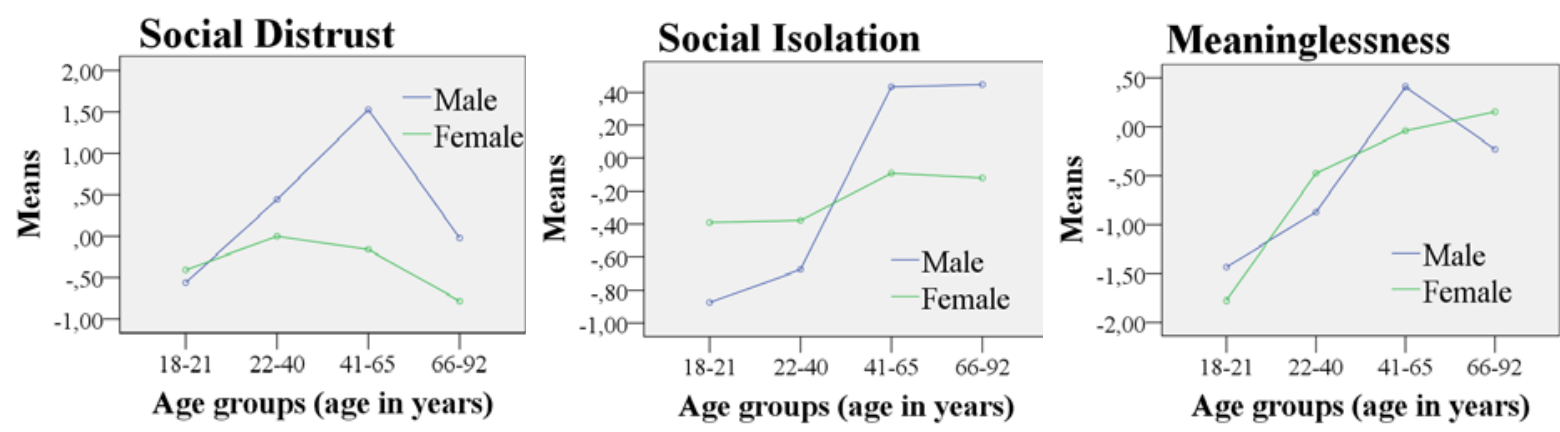

Figure 2. The levels of Social Distrust, Social Isolation and Meaninglessness for male and female respondents from different age groups

To assess whether males and females from different age groups have different Anomia Scales composite scores, and whether there was an interaction between age and gender, a multivariate analysis of variance (two-factor MANOVA) was conducted. The assumption of homogeneity of covariances 
across groups was checked and met. It was found that the interaction between sex and age was not significant, Wilks' $\Lambda=.985, F(9,1927.67)=1.36, p=.05$, multivariate $\eta^{2}=.01$. There was a statistically significant difference in multidimensional anomia between Latvian inhabitants of different age groups, Wilks' $\Lambda=.956, F(9,1927.67)=4.08, p=.00$, multivariate $\eta^{2}=.02$. The main effect for sex was not significant, Wilks' $\Lambda=.996, F(3,792)=.98, p=.05$, multivariate $\eta^{2}=.00$.

Follow-up ANOVAs (see Table 2) indicate that there were statistically significant differences between respondents of different age groups for Social Isolation scores and for Meaninglessness scores.

Table 2. Effects of Age and Sex on Anomia Scales Composite Scores

\begin{tabular}{ccrrrr}
\hline Source & Dependent variable & $\boldsymbol{d} \boldsymbol{F}$ & $\boldsymbol{F}$ & $\boldsymbol{\eta}^{\mathbf{2}}$ & $\boldsymbol{p}$ \\
\hline Age & Social Distrust & 3 & 2.49 & .01 & .059 \\
& Social Isolation & 3 & 5.27 & .02 & .001 \\
\multirow{3}{*}{ Sex } & Meaninglessness & 3 & 8.20 & .03 & .000 \\
& Social Distrust & 1 & 2.73 & .00 & .099 \\
\multirow{3}{*}{ Age x Sex } & Social Isolation & 1 & .11 & .00 & .736 \\
& Meaninglessness & 1 & .00 & .00 & .986 \\
\multirow{2}{*}{ Error } & Social Distrust & 3 & 1.27 & .01 & .284 \\
& Social Isolation & 3 & 1.95 & .01 & .121 \\
& Meaninglessness & 3 & .34 & .01 & .259 \\
& Social Distrust & 794 & & & \\
\hline
\end{tabular}

Additionally Post hoc tests using Games-Howell were performed for multiple comparisons of Social Isolation and Meaninglessness scores for respondents from different age groups. The results of Post Hoc tests showed that respondents aged between 41 and 65 years (middle adulthood) had significantly higher scores for Social Isolation than 22-40 years old respondents (early adulthood) $(p<.05)$. It was also found that 18-21 years old respondents (late adolescence/youth) had significantly lower scores for Meaninglessness than respondents aged between 22 and 40 years (early adulthood) $(p<.05)$, respondents aged between 41 and 65 years (middle adulthood) $(p=.00)$, and respondents aged between 66 and 92 years (late adulthood) $(p=.00)$. It was also found that 22-40 years old respondents (early adulthood) had significantly lower scores for Meaninglessness than respondents aged between 41 and 65 years (middle adulthood) $(p<.01)$, and respondents aged between 66 and 92 years (late adulthood) $(p<.05)$. 


\section{Conclusions}

The present study was designed to investigate the level of anomia of Latvian inhabitants. The aim of this study was to examine whether there were differences in levels of anomia for males and females from different age groups.

The results of the present research show that there are age differences in levels of anomia for Latvian inhabitants. In particular, it was found that middleaged adults had higher scores for Social Isolation than respondents from the group of early adults. This finding has at least two possible explanations. First, from the developmental perspective it can be connected with the developmental changes such as changes in the family structure - middle-aged adults can feel more social isolation and have the higher ratings of lack of social support and sense of loneliness because their the grown-up children leave home and start living separately from parents. Second, middle-aged adults reported an elevated level of social isolation than early adults because they can have less possibilities for social inclusion and participation offered by the Latvian society.

It was also found that Latvian inhabitants from the group of late adolescents-youths had the lowest scores for Meaninglessness comparing with all other age groups, and early adults - lower scores for Meaninglessness than middle and late adults. First, late adolescents and youths feel less meaninglessness than respondents from all other age groups because late adolescence-youth is the stage of psychosocial development when the life of a young man is filled with future plans and hopes. Second, adolescents and youth as well as early adults can have the lower ratings of being without desirable and worthwhile goals and pessimism about the future because they can be more flexible, easier accept social, political and economic changes and, as a result, they can easier find the new goals in the new socially economic conditions.

Sex differences in levels of anomia were not found. These findings allows to propose that, perhaps, socially and environmental factors are more important for the sense of anomie that biologically determined factors.

The paper was supported by the National Research Program 5.2. "Economic Transformation, Smart Growth, Governance and Legal Framework for the State and Society for Sustainable Development - a New Approach to the Creation of a Sustainable Learning Community (EKOSOC-LV)"

\section{References}

Cao, L., Zhao, R., Ren, L., \& Zhao, J. (2010). Social support and anomie: A multilevel analysis of anomie in Europe and North America. International Journal of Offender Therapy and Comparative Criminology, 54 (4), 625-639.

Craig, G.J. \& Baucum, D. (2001). Human Development (9th Edition). New York: PrenticeHall.

European Quality of Life Survey (EQLS). (2012). Downloaded from http://eurofound.europa.eu/surveys/eqls 


\section{SOCIETY. INTEGRATION. EDUCATION. Volume III}

Dean, D. (1961). Alienation: Its meaning and measurement. American Sociological Review, $26(5), 753-758$.

Durkheim, É. (1964) [1893]. The Division of Labour in Society. NY: Free Press.

Durkheim, É. (1966) [1951]. Suicide: A Study in Sociology. NY: The Free Press.

Lytkina, E. (2012). From anomie to alienation: An approach towards the measurement of social well-being and deviance. Papers of the IV Russian Sociology Congress. Moscow: Institute of Sociology RAN, Russian Sociological Society, 8227- 8231.

Ļevina, J., Mārtinsone, K., \& Kamerāde, D. (2015, a). A model of anomia in the Baltic States. Submitted for publication in The Interdisciplinary Social Sciences Collection.

Ļevina, Mārtinsone, \& Kamerāde, (2015, b). Individuālās anomijas modeļi Latvijas populācijā. Iesniegts un akceptēts publicēšanai RSU 2015.gada Zinātniskās konferences tēžu krājumā.

Levina, J., Martinsone, K., Kolesnikova, J., \& Perepjolkina, V. (2014). Possibilities of research of anomie in Latvian society. In A. Vētra, A.Vilks (Eds.) 5th International Interdisciplinary Scientific Conference ,, Society. Health. Welfare”. 2nd Conference of Speech Therapists (Rīga, November 26-28, 2014): Abstracts (p.39). Rīga: RSU.

Merton, R. K. (1962) [1957]. Social Theory and Social Structure. Glencoe, Illinois: Free Press.

Merton, R. K. (1964). Anomie, Anomia, and Social Interaction: Contexts of Deviant Behavior. In M. B. Clinard (Ed.) Anomie and Deviant Behavior: A Discussion and Critique (pp. 213-242). NY: Free Press.

Metha, A. (1972). Existential Frustration and Psychological Anomie within Select College Student Subcultures. Dissertation. Los Angeles: University of Southern California Downloaded from http://digitallibrary.usc.edu/cdm/compoundobject/collection/ p15799coll18/id/503255

Olsen, M. (1965). Two categories of political alienation. Social Forces, 47, (3), 288-299.

Richmond, B. D. Mason, R. L., \& Smith, V. (1969). Existential Frustration and Anomie. Journal of National Association of Women Deans and Counselors, 32, 136-138.

Seeman, M. (1959). On the meaning of alienation. American Sociological Review, 24 (6), 783-791.

Sev'er, A., Isajiw, W., \& Driedger, L. (1993). Anomie as powerlessness: Sorting ethnic group prestige, class, and gender. Canadian Ethnic Studies, 25 (2), 84-99.

Seeman, M. (1982). A Prolegomenon on Empirical Research Regarding Anomie. In S. G. Shoham \& A. Grahame (Eds.) Alienation and Anomie Revisited (pp. 121-138). Tel Aviv, Israel: Ramot.

Srole, L. (1956). Social integration and certain corollaries: An exploratory study. American Sociological Review, 21, (6), 709-716.

Zhao, R. \& Cao, L. (2010). Social change and anomie: A cross-national study. Social Forces, 88 (3), 1209-1230.

Лыткина, Е. И. (2014). Аномия: новый подход к операционализации классического понятия. XIV Апрельская международная научная конференщия по проблемам развития экономики и общества: в 4-х книгах. Книга 4. Отв. ред.: Е. Г. Ясин. М., Издательский дом НИУ ВШЭ, стр. 152-161. 